\title{
Prevalence and associated Factors of Malnutrition, among Children 6-59 months old in Pastoral communities of Aweil Centre, South Sudan
}

\author{
Article Ratib Dricile ${ }^{\mathbf{1} 2}$ \\ ${ }^{1}$ Texila American University, George Town Guyana \\ ${ }^{2}$ Health and Development for All (HADA), Kampala Uganda \\ E-mail: dricileratib@yahoo.co.uk ${ }^{1}$
}

\begin{abstract}
Malnutrition is one of the leading causes of morbidity and mortality among children globally has been linked to $60 \%$ of the 10.9million deaths annually of children under five. The median stunting prevalence in WHO African region is $31.3 \%$.

Aweil Center of South Sudan has consistently high malnutrition rates despite running nutrition projects with relative stability. Results from nutrition survey in November 2013 indicated a severe acute malnutrition (SAM) prevalence rate of $6.3 \%$ (95\% CI, 4.5-8.9) and a global acute malnutrition (GAM) rate of $22.4 \%$ (95\% CI, 17.8-27.7). Both prevalence rates were above the WHO thresholds of $15 \%$ and $2 \%$ respectively.

A cross-sectional study done with two-stage cluster sampling method showed that generally children 659 months in Aweil Center have poor nutritional status with GAM (<-2 z-score and/or edema) of 23.2\% (95\% CI, 19.0-27.9) and SAM (\% < -3SD) of 7\% (95\% CI, 4.9\%-9.9\%). However, stunting based on height/length-for-age z-scores was $8.7 \%$ (95\% CI, 6.5-11.6), which was within the acceptable new WHO's threshold regarded as low probably due to genetic factors for tallness for Dinka tribe.

The study revealed high burden of infectious diseases at $94.5 \%$ with p-value 0.00022 (95\%C. I, 0.1667-0.291). Poor feeding and family planning practices; poor access roads to markets contribute to childhood malnutrition.

Multifaceted approach is needed to root out the chronic malnutrition from Aweil center shift from food Aid to support of food production, scale up of primary health care and iCCM interventions and community awareness on feeding practices among others.
\end{abstract}

Keywords: Prevalence, Associated-factors, Malnutrition, Children 6-59 months, Infectious diseases, Genetics.

\section{Introduction}

Malnutrition is one of the most common causes of morbidity and mortality among children globally (WHO1999). Malnutrition has been linked to $60 \%$ of the 10.9 million deaths annually of children less than five years old. Not only that; 50-70\% of the burden of diarrhea, malaria, and respiratory infections among others in childhood are attributed to undernutrition with underlying poverty (WHO2003). Infants born with low birth weight (LBW) are 1.74 times more likely to be stunted (95\% CI, 1.38-2.19) than those born with normal weight (Aryastami et al 2017).

Undernutrition is still persistent in the WHO African region with major implications for health care. Sadly Twenty five of the WHO African region's 47 countries have high (>30\%) or very high (>40\%) rates of stunting (WHO 2017). Within Africa, Sub-Saharan Africa has one of the highest rates of underfive malnutrition with stunting as high as $57.7 \%$ in the East African Country of Burundi, $43.9 \%$ in Niger of West Africa and 39.9\% in Chad of Central Africa (Akombi et al, 2017).

It has been noted that stunted mothers of reproductive age are more likely to have stunted children. This is because the genes for stunted growth are passed on to the next generation in their children (Thokozani 2014). 
Data collected from 45 Countries between 2007 and 2015 showed median wasting of $6.3 \%$ and ranged from 2\% in Swaziland to $22.7 \%$ in South Sudan. 17 Countries had wasting level less than 5\% (acceptable prevalence), 19 countries had wasting prevalence of 5-9\% (poor prevalence); 3 Countries exceeded the critical public health emergency threshold. These included South Sudan at $22.7 \%$, Niger $18.7 \%$ and Eritrea $15.3 \%$ (WHO 2017).

Aweil Centre of South Sudan is one of the Counties with Chronic and acute Malnutrition especially among children under the age of 5 years. Results from a nutrition survey conducted in November 2013 indicated a severe acute malnutrition (SAM) prevalence rate of $6.3 \%$ (95\% CI, 4.5-8.9) and a global acute malnutrition (GAM) rate of $22.4 \%$ (95\% CI, 17.8-27.7). Both prevalence rates were above the WHO global acute malnutrition and severe acute malnutrition rates of $15 \%$ and $2 \%$ respectively. The high malnutrition rates continue to exist among the preschool children in South Sudan after surviving the 6-59 months of age (Harvey and Rogers 2007).

The government, UN agencies and implementing partners have a number of nutrition and health projects running in the County, but the malnutrition rates have remained high despite the relative stability in this region compared to the neighboring states of lakes, Western Bahr el Ghazal and Unity states that are at the heart of the conflict in South Sudan. There was need to find out the current prevalence of malnutrition and the associated actors of the persistent under nutrition among the children 6-59 months so as to address the root causes of the malnutrition in this pastoral communities. There was therefore a need to establish the Current malnutrition rates and the associated factors as to give recommendations to address the underlying causes of malnutrition in Aweil Centre County.

Timely and adequate feeding of children 6-59 months with foods rich in proteins, carbohydrates, oils and micronutrients increases their chances of survival, supports growth and development especially in the first 2 years of life. In addition, improving maternal nutrition, especially before, during and immediately after pregnancy reduces stunting and acute malnutrition (United Nations 2015).

Neonates need to be breastfed in the first 1hour of their life, creating early bonding with mother, provision of colostrum which is rich in nutrients and supports the immune system for the bay and keeps baby warm-protecting from hypothermia which can be life threatening.

Infants should be exclusively breastfed for the first 6 months of their life. Adequate feeding from 6 months to 59 months and above prevents stunting and reduces the risk of infectious diseases like pneumonia and infective diarrhea among others, hence reducing morbidity and mortality among the children less than five years of life (UNICEF 2015).

Due to the collapsed health systems and poor health infrastructure in South Sudan following the years of conflict, community management of acute malnutrition (CMAM) was introduced in the year 2000. Community mobilization is key for the success of CMAM program because this is where the children who are malnourished are screened and referred by community-based distributer (CBDs) volunteers either to OTP, SFP at the PHC facilities or stabilization Centre at the state capital in Aweil (Keane et al 2013).

\section{Research methodology}

\section{Study area}

The study was conducted in Aweil center County, one of the five Counties of the former Northern Bahr el Ghazal state of South Sudan.

Aweil town is the capital of former Bahr el Ghazal state and now capital of Aweil state, located $800 \mathrm{KM}$ from Juba, the capital of Juba and lies on the North West part of the Country at coordinates of $8^{\circ}$ 46' 02.00"N, $27^{\circ} 23^{\prime} 59.00 " \mathrm{E}$ (Latitude: 8.7671; Longitude: 27.3998). Its location is near the international border with the Republic of Sudan and the Abyei region to the north, bordering Wau to the South, Lol state of former Western Bahr el Ghazal to the West and Aweil East County to the east. Aweil Center County has 7 Payams which are administrative units. These include Achanna, Aroyo, Awada, Awulic, Bar Mayen, Chel South and Nya lath. The Payams are sub- divided into 29 Bomas, the smallest administrative unit in the republic of South Sudan. 
The topography of Aweil is flat with savannah grassland devoid of most of its trees for firewood, charcoal and shelter, hence making this Country prone to flooding every year at the peak of rainy season from August to October. The soils are silty making them retain flood water for weeks and sometimes even months blocking transport from some villages to the town center which lies close to the confluence of Lol and Pongo Rivers. There are two weather conditions all in the extreme: prolonged dry season from November to May and flooding from August to October.

Unlike the neighboring counties that are predominantly one tribe, Aweil has Luo and Dinka tribes sandwiched with other tribes and nationalities socially living in harmony. This is the most peaceful state of the ten states in South Sudan. Different tribes living side by side and different faiths pray side by side. The main economic activities are cattle keeping since most of the villagers are pastoralist who move with cattle to look for pasture during dry season and mover to high grounds near the town during the floods at peak of the rain. A good proportion of the population does mixed farming with growing of crops and rearing of smaller number of animals. Others along the Lol and Pongo rivers do some fishing. Foreigners are mostly in the town and are involved in cross border trade with neighboring Countries like Uganda, DRC, Kenya and Sudan. Despite these economic activities, poverty level is the worst in the country at $76 \%$ (fig2).

The former Northern Bahr el Ghazal had a population of 720,898 (55,398 urban and 665,500 rural) and an area of 30,543 square kilo meters with population density of 24/sq. $\mathrm{km}$. Aweil Center has lion's share of the land of the 5 Counties at 11,17 sq. $\mathrm{km}$, but the smallest population $41,827(22,199 \mathrm{M} 19,628 \mathrm{~F})$ and 5919 (16\%) children 6-59 months with population density of only 4 / sq. km (GOSS and SSCCSE 2010).

South Sudan has one of the worst health indicators with infant mortality rate at 79 deaths per 1000 live births, but the highest infant mortality rates are in the former Northern Bah El Ghazal state at 120 deaths per 1,000 live births and also under five mortality rate at 152 deaths per 1,000 live births.

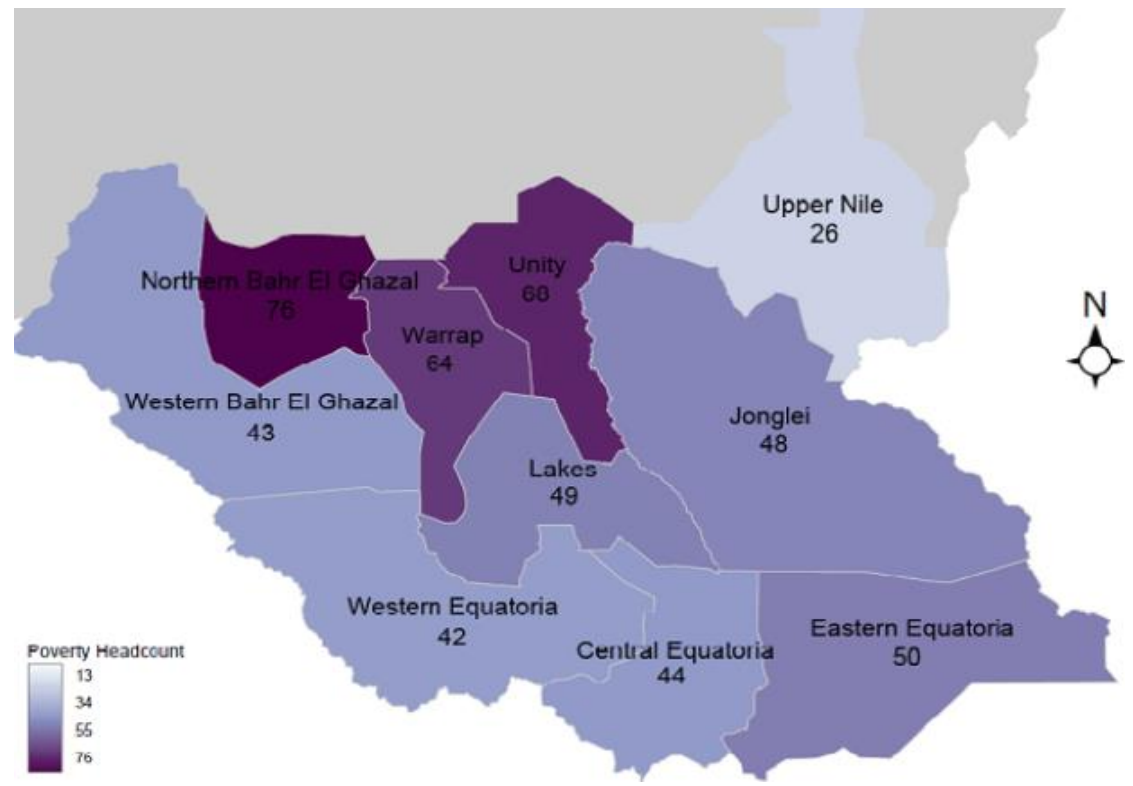

Figure 2. Poverty headcount in south sudan. source: poverty in southern sudan: national baseline household survey (NBHS), 2010

\section{Theoretical framework}

The high prevalence of pathogens especially bacteria, and parasites in developing countries of SubSaharan Africa contributes greatly to the malnutrition and vice versa contributing to 300,000 deaths per year which directly related to severity of malnutrition and poverty which is the main underlying cause of 
malnutrition (Müller and Krawinkel, 2005). Figure3 below illustrates the theoretical framework of the causes of malnutrition in Aweil, 2018.

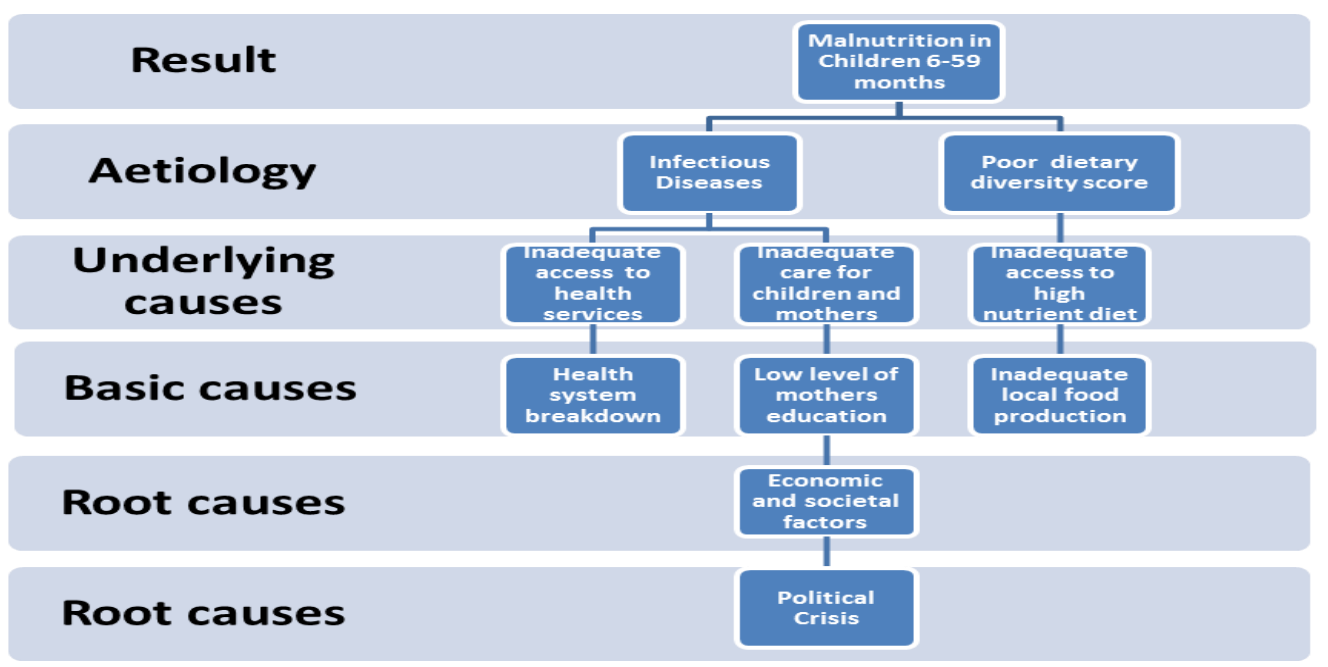

Figure 3. Theoretical framework for causes of malnutrition in Aweil 2018

\section{Research design}

A community based cross-sectional study design was applied for children and their care takers. A twostage cluster sampling method was adopted to select the villages and the households. A total of 39 clusters (villages) were selected, 9 of which were reserves. One child (6-59 months) in the selected household was randomly included in the anthropometric assessment and the care taker interviewed using interviewer administered questionnaire to get more information on the associated factors of malnutrition. Using village lists provided by the County health department, village level enumerators were trained to do systematic random sampling to select 13 households per cluster who were then interviewed. The 30 cluster $* 13$ household per cluster survey design enabled the calculation of $95 \%$ confidence interval point estimates to give 390 households as the minimum number of households, children and their care takers. ${ }^{1}$

An unmatched case-control study of children 6-59 months malnourished and well-nourished was done. The malnourished children were the cases of moderate acute malnutrition (MAM - a weight for height $Z$ score of $\geq-3 \mathrm{SD}$ to $<-2 \mathrm{SD}$ ) or severe acute malnutrition (SAM-a weight for height $\mathrm{Z}$ score of $<-3$ Standard deviations with or without bilateral pitting edema). The well-nourished children were controls and compared with the cases in a $3 \mathrm{X} 3$ design using various parameters of age, monthly family income, age of sibling that child follows, mother's education level among others.

Research Variables:

The research variables are grouped into three: anthropometrics and health for the children 6-59 months, infant and young child feeding practices (IYCF) and food security. To ensure that the respondents understood the message, the structured questionnaire was translated to Dinka language and back to English to confirm the translation.

Anthropometric measurements included weight, and height or length and the dependent variables. Vitamin A supplementation in the last six months, Measles vaccination for children 9 months and above, any history of illness two weeks prior to the day of administering the questionnaire, for example fever, cough, diarrhea, skin infections, and eye infections.

The facility in which sick child is taken for treatment like primary health care unit (PHCU), primary

\footnotetext{
${ }^{1}$ https://www.who.int/immunization/monitoring_surveillance/Vaccination_coverage_cluster_survey_with_annexes.p
} df 
health care Centre (PHCC), hospital, outreach clinic, private physician, village health worker, Community-based drug distributor (CBD), drug shop, traditional practitioner, relative or a friend.

Variables related to malaria control included the number of long-lasting insecticide treated nets (LLITNs) and whether or not the child 6-59 months is sleeping under LLITNs. Also related to malaria, diarrhea cough is accessibility to a CBD.

The variables under IYCF included age of the child in months, whether the child has ever been breast fed, if yes how long after birth it took before the child was first put in to breast feed; whether immediately $(<1 \mathrm{hr}), 1-24 \mathrm{hrs}, 24-48 \mathrm{hrs}$, or after 48 hours. At what age other foods were introduced to the child and what foods were they?

\section{Food security variables}

Various food groups consumed in the past 24 hours before the day of administering questionnaire; for example breast milk, milk and other dairy products like yoghurt, fruits, green leave vegetables, sugar, honey, oil, fats or butter pulses like beans, lentils, groundnuts, sesame or peas; cereals like maize, sorghum, millet, rice, pasta, bread, and tubers; for example cassava, potatoes, and sweet potatoes among others. The individual dietary diversity (IDDS) of the children in the community was calculated using the formula:

$$
I D D S=\text { Number of children (6-59) months who received food from at least four (4) food groups }
$$
in 24 hrs.

$X 100$

Number of children (6-59 months) enrolled in the study

At household level, the number of times the various food groups were consumed in the past 7 days prior to the day of study was also recorded just like for the 24 hour period (FAO 2010).

\section{Sample size, design effect and precision}

The design effect and precision were calculated using the formula:

\pm 2 standard errors $(s)=\sqrt{ }[\mathrm{p}(1-\mathrm{p}) \mathrm{D} / \mathrm{n}]$

Note: $s=\sqrt{ }[p(1-p) D / n]$ is an extension of the simpler formula binomial formula $\sqrt{ }[p(1-p) / n]$ when the data is assumed to come from a simple random sample.

$\sqrt{ } \mathrm{D}$ is a measure of the increase in the standard error of the estimate due to the sampling procedure used.

\section{\pm 2 Standard errors $(s)=V[p(1-p) D / n]$}

Where $\mathrm{D}$ is design effect $=1+(\mathrm{b}-1)$ roh

And roh= rate of homogeneity. 0.2 at $95 \%$ or 0.1 at $50 \%$

$\mathrm{b}=$ average number of responses per cluster

$\mathrm{n}=$ total number of responses in the study

$\mathrm{p}=$ estimated proportion $=0.5-$ not known

No. of clusters necessary(c) $C=p(1-p) D / S^{2} b$ (Bennett $S$ et al 1991)

Sample size, $\mathrm{n}=\left((\mathrm{za} / 2)^{2}\right) / \mathrm{s}^{2}[\mathrm{p}(1-\mathrm{p})]^{*} \mathrm{D}$

Where $\mathrm{za} / 2=\mathrm{Z}$-score equivalent to1.96

$\mathrm{S}=$ standard error $=0.05$

$\mathrm{P}=$ proportion $=0.5$

$\mathrm{n}=\left(1.96^{2}\right) /\left(0.05^{2}\right)[0.5(1-0.5) * 1.5$

$\mathrm{n}=576.24$

Expected response rate $95 \%$ 
DOI: 10.21522/TIJPH.2013.SE.19.01.Art012

ISSN: $2520-3134$

$\mathrm{n}=576.24 * 0.95=547$ households and children 6-59 months as well as care takers (mothers)

\section{Sampling technique}

Selection of the sample was performed by sampling with probability proportional to size (PPS). This was carried out by making a table of cumulative list of village populations and selecting a systematic sample from a random start. The total population of the clusters (villages) was divided by the estimated number of villages to be selected to obtain the sampling interval (SI). Random number was chosen between 1 and the SI then fitted into position to identify the first village in the sample frame. Then the SI was added to the random number to get the second village and the SI was added to cumulative number to get the subsequent villages. Constant number of households was selected from each selected village so that each household in the population had the same probability of being selected in the sample i.e. selfweighting sampling procedure.

\section{Inclusion/exclusion criteria}

Children from the selected clusters and homes from Aweil center County 6-59 months of age were included in the study. Only one child 6-59 months was selected per household to avoid double selection. Additional children in the same household were excluded. Children were not eligible to participate if they were not accompanied by responsible caretaker to get informed consent.

\section{Research equipment and materials}

The standardization test equipment and materials included 12 new MUAC tapes, wooden height boards with calibration, twelve (12) electronic weighing scales with two extra sets of batteries, one 50-pen box, standardization test forms and 16 clipboards (one per participant).

\section{Data analysis}

Data from the field was checked for errors before entry was made in the nutrition survey database in the world health organization (WHO) anthro software version 3.2.2.1. The anthropometric data and that for nutrition factors were then exported to SPSS for analysis. Bivariate analysis and multivariate regression analysis were then done to get prevalent of malnutrition, and the associated factors.

\section{Ethical considerations}

Ethical clearance was sought from the directorate of policy, planning and budgeting in the Ministry of health, republic of South Sudan. Bonafide certificate was provided by the Texila American University to introduce me officially to the authorities and confirming that I'm a student.

The state ministry of health and the County health departments were informed of the planned nutrition study and protocol shared with them to familiarize themselves with the purpose and the research process.

\section{Results}

\section{Demography}

A total of 517 children and their care takers were reached. 217(42\%) of the children were males and $297(58 \%)$ were females. Out of 517 children 514 care takers were able to give all the needed information which was $99.42 \%$ response rate. 55(10.7\%) of the children were infants and the highest number of children in a single age bracket was $128(25 \%)$ within 12-23 months of age. The rest of the children were between 24 and 59 months of age with more or less uniform distribution (fig6) 


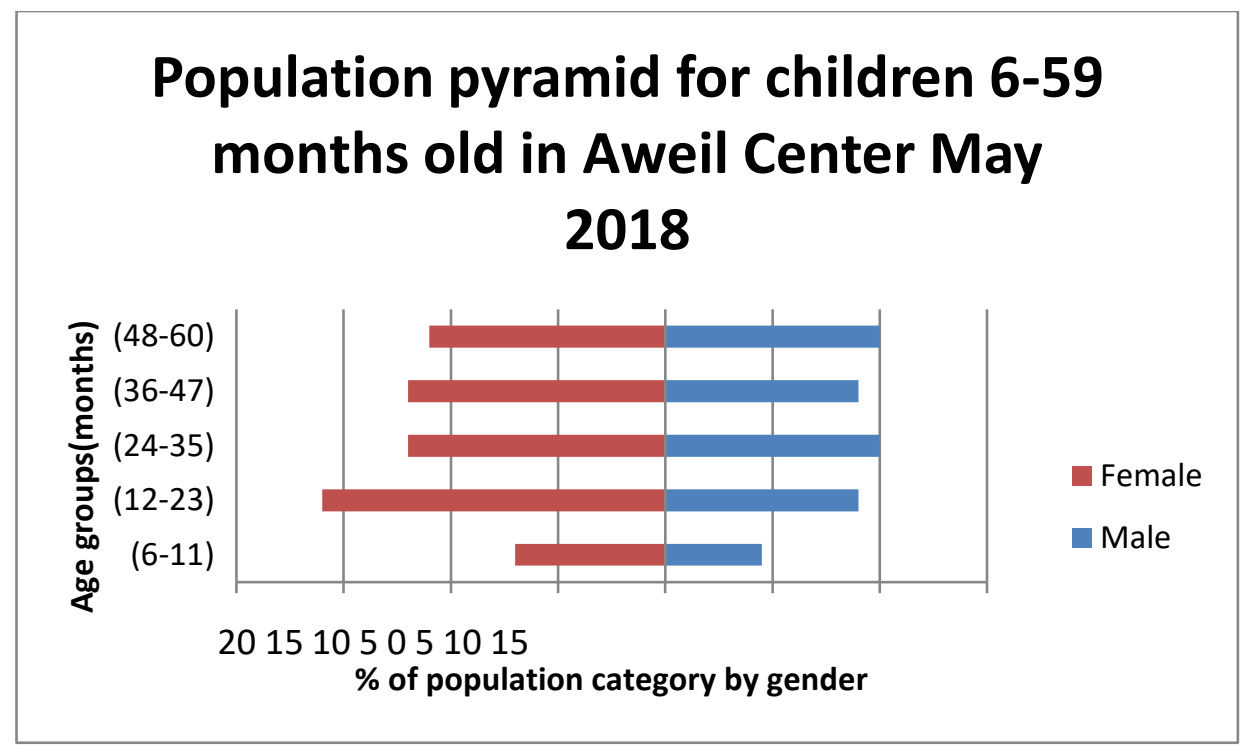

Figure 6. Population pyramid for children 6-59 months in Aweil center Prevalence of malnutrition

The results showed that generally children 6-59 months in Aweil Center have poor nutritional status compared to the WHO standard. This has been reflected in Fig7 below with the curve of z-score in red shifted to the left of the WHO standard in green on the right with the prevalence of global acute malnutrition -GAM (<-2 z-score and/or edema) [119] 23.2\%. Prevalence of severe acute malnutrition (SAM) $(\%<-3 \mathrm{SD})$ was $7 \%$ in Aweil which was also higher than the WHO threshold of $2 \%$ (95\% CI, 4.99.9) (table3).

Prevalence of underweight based on weight-for-age z-scores was $16.6 \%$ (95\% CI, 13.8- 19.7). Boys were more likely to be underweight compared to girls with prevalence $19.8 \%$ (95\% CI, 15.6-24.8) and $14.1 \%$ (95\% CI, 10.4-18.9) respectively (table4).

Prevalence of stunting based on height/length-for-age z-scores was $8.7 \%$ (95\% CI, 6.5-11.6), which is was also within the acceptable new WHO's threshold regarded as low. However, children between 12-23 months had the highest level of stunting at $11.7 \%$ (95\% C.I. 6.4-26.7) (Table5). 
DOI: 10.21522/TIJPH.2013.SE.19.01.Art012

ISSN: 2520-3134

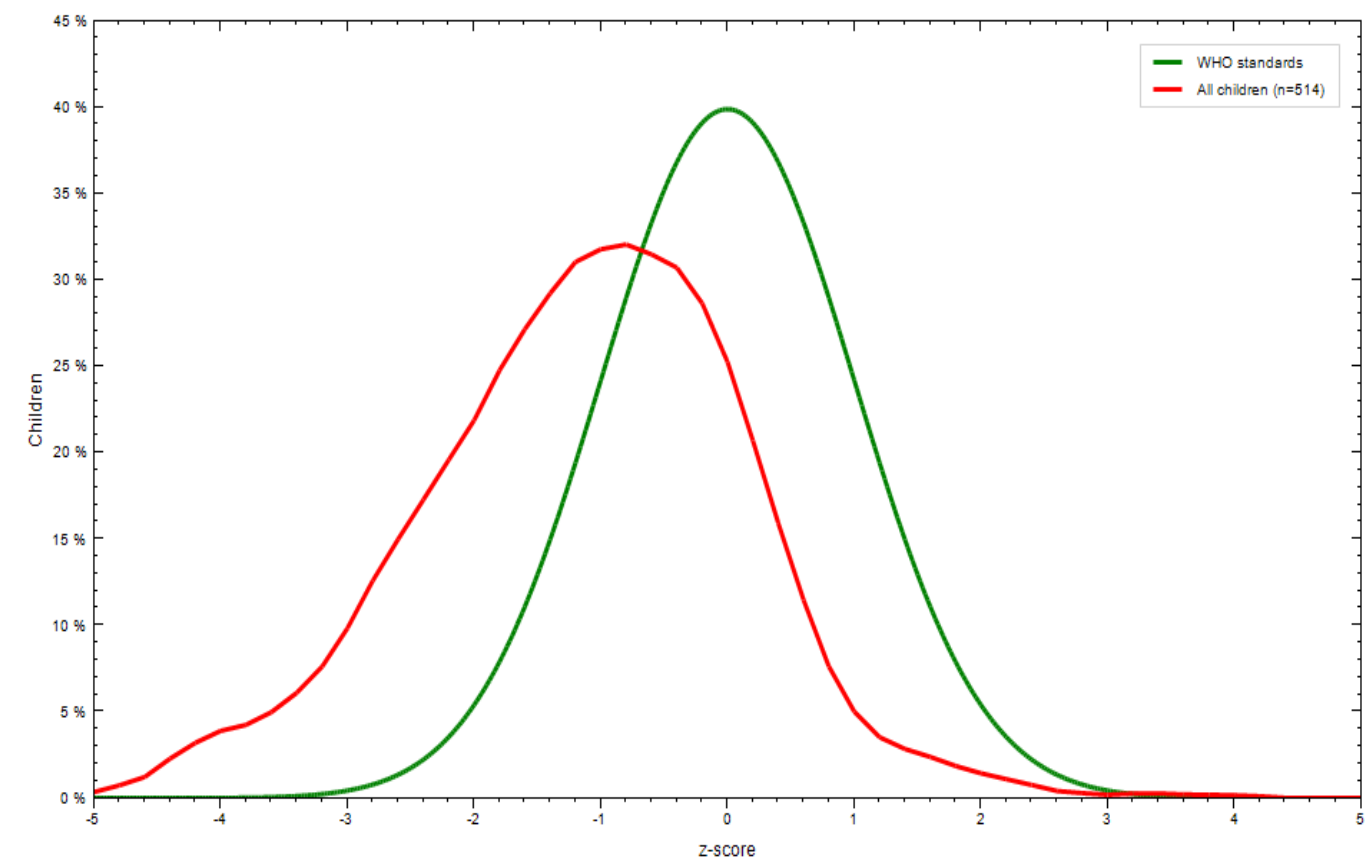

Figure 7. General nutritional status of the children in Aweil compared with WHO standard

\section{Set 1- General results}

Table 6. Prevalence of malnutrition by age group for gender combined children 6-59 months

\begin{tabular}{|l|l|l|l|l|l|}
\hline Age groups & $\mathbf{N}$ & \multicolumn{3}{|l|}{ Weight-for-length/height (\%) } & \\
\hline & & $\%<-3 \mathrm{SD}$ & $(95 \% \mathrm{CI})$ & $\%<-2 \mathrm{SD}$ & $(95 \% \mathrm{CI})$ \\
\hline Total: & 514 & 7 & $(4.9-9.9)$ & 23.2 & $(19-27.9)$ \\
\hline$(6-11)$ & 55 & 1.9 & $(0.3-12.8)$ & 25 & $(15.7-37.4)$ \\
\hline$(12-23)$ & 128 & 5.5 & $(2.6-11.3)$ & 17.2 & $(11.1-25.6)$ \\
\hline$(24-35)$ & 108 & 5.6 & $(2.7-11.1)$ & 21.3 & $(13-32.9)$ \\
\hline$(36-47)$ & 107 & 10.3 & $(5-20)$ & 29.9 & $(19-43.7)$ \\
\hline$(48-60)$ & 107 & 9.3 & $(5.2-16.2)$ & 24.3 & $(15.4-36.1)$ \\
\hline
\end{tabular}

Table 7. Prevalence of acute malnutrition based on $\mathrm{W} / \mathrm{H}$ z-scores and edema disaggregated by gender

\begin{tabular}{|l|l|l|l|}
\hline Variables & All N=514 & Boys n=217 & Girls=297 \\
\hline $\begin{array}{l}\text { Prevalence of global acute } \\
\text { malnutrition -GAM (<-2 z-score } \\
\text { and/edema) }\end{array}$ & $\begin{array}{l}{[119] 23.2 \%} \\
(95 \% \text { CI, 19.0-27.9) }\end{array}$ & $\begin{array}{l}{[55] 25.3 \%} \\
(95 \% \text { CI, 19.3- } \\
32.5)\end{array}$ & $\begin{array}{l}{[64] 21.5 \%(95 \% \text { CI, }} \\
16.1-28.2)\end{array}$ \\
\hline $\begin{array}{l}\text { Prevalence of moderate } \\
\text { malnutrition (<-2 z-score and } \\
>=-3 \text { z-score, no edema) }\end{array}$ & $\begin{array}{l}{[83] 16.2 \%} \\
(95 \% \text { CI, 14.1-18.0) }\end{array}$ & $\begin{array}{l}137] 17 \%(95 \% \text { CI, } \\
14.19 .0)\end{array}$ & $\begin{array}{l}{[46] 15.4 \%(95 \% \text { CI, }} \\
12.5-18.3)\end{array}$ \\
\hline $\begin{array}{l}\text { Prevalence of severe } \\
\text { malnutrition (<-3 z-score } \\
\text { and/edema) }\end{array}$ & $\begin{array}{l}\text { [36] 7\% } \\
(95 \% \text { CI, 4.9-9.9) }\end{array}$ & $\begin{array}{l}{[18] 8.3} \\
(95 \% \text { CI, 5-13.5) }\end{array}$ & $\begin{array}{l}{[18] 6.1 \%(95 \% \text { CI, }} \\
3.6-9)\end{array}$ \\
\hline
\end{tabular}


Table 8. Comparison of prevalence of underweight based on weight-for-age z-scores for male and female

\begin{tabular}{|l|l|l|l|l|l|l|}
\hline & Under Weight & \multicolumn{2}{|l|}{ Weight-for-age (\%) } & & & \\
\hline Category & $\mathrm{N}$ & $\%<-3 \mathrm{SD}$ & $(95 \% \mathrm{CI})$ & $\%<-2 \mathrm{SD}$ & $(95 \% \mathrm{CI})$ & $\mathrm{SD}$ \\
\hline Total: & 507 & 4.1 & $(2.8-6.2)$ & 16.6 & $(13.8-19.7)$ & 1.07 \\
\hline Male & 217 & 2.8 & $(1.3-5.7)$ & 19.8 & $(15.6-24.8)$ & 0.98 \\
\hline Female & 290 & 5.2 & $(3-8.8)$ & 14.1 & $(10.4-18.9)$ & 1.12 \\
\hline
\end{tabular}

Table 9. Prevalence of stunting based on height/length-for-age z-scores

\begin{tabular}{|c|c|c|c|c|c|}
\hline Age groups & $\mathbf{N}$ & \multicolumn{3}{|c|}{ Length/height-for-age (\%) } & \\
\hline & & $\%<-3 \mathrm{SD}$ & $(95 \% \mathrm{CI})$ & $\%<-2 \mathrm{SD}$ & $(95 \% \mathrm{CI})$ \\
\hline Total: & 505 & 2.4 & $(1.4 \%, 4.1 \%)$ & 8.7 & $(6.5 \%, 11.6 \%)$ \\
\hline$(6-11)$ & 55 & 0 & $(-,-)$ & 5.8 & $(2 \%, 15.3 \%)$ \\
\hline$(12-23)$ & 128 & 2.3 & $(0.8 \%, 6.8 \%)$ & 11.7 & $(6.9 \%, 19.1 \%)$ \\
\hline$(24-35)$ & 108 & 5.6 & $(2.6 \%, 11.7 \%)$ & 12 & $(6.2 \%, 22 \%)$ \\
\hline$(36-47)$ & 106 & 0.9 & $(0.1 \%, 6.9 \%)$ & 4.7 & $(1.9 \%, 11.2 \%)$ \\
\hline$(48-60)$ & 108 & 1.9 & $(0.5 \%, 7.1 \%)$ & 7.4 & $(3.6 \%, 14.5 \%)$ \\
\hline
\end{tabular}

\section{Factors associated with malnutrition}

\section{Bivariate analysis}

The study results show that vitamin A supplementation for children 6-59 months old was 273(53\%), pvalue 0.0006 and odds ratio (OR) 0.47 (95\% C.I. 0.31-0.72) which was significant protective measure against malnutrition (Fig9 and Table 16: section 1).

Measles vaccination with evidence from a vaccination card $284(55 \%)$ p-value 0.005 and OR 0.54 (95\% C.I. 0.36-0.82) which was significant and contributes to reduction in the prevalence of malnutrition $273(53 \%)$ of the children were reported to be sleeping under long lasting insecticide treated mosquito nets. P-value was 0.01 and OR 0.57 (95\% C.I. 0.37-0.86) which is statistically significant and protective. (table16: section 2 and 7).

Within 30 days prior to the study, 361(0\%) families enrolled in the study had lacked food or money for food for at least once. Malnutrition rate in these families was one of the highest with 101 children under five (28\%) malnourished. P-value was 0.0001 and OR 2.96 (95\% C.I. 1.72-5.09) which was significant and scarcity of resources increased the risk of malnutrition.

Table 16. Bivariate analysis of various factors of malnutrition with their p-values, Odds ratio and $95 \%$ confidence intervals

\begin{tabular}{|l|l|l|l|l|l|l|l|l|l|}
\hline S & FACTOR & NO & $\mathbf{\%}$ & & & \multicolumn{2}{|l|}{ P-V } & OR & \multicolumn{2}{|l|}{ LIMITS } \\
\hline $\mathbf{1}$ & $\begin{array}{l}\text { Vitamin A } \\
\text { supplementation }\end{array}$ & No. & $\mathbf{\%}$ & $\begin{array}{l}\text { Malnutr } \\
\text { ition }\end{array}$ & $\begin{array}{l}\text { No } \\
\text { malnutriti } \\
\text { on }\end{array}$ & $\begin{array}{l}\boldsymbol{P} \text { - } \\
\text { value }\end{array}$ & OR & $\begin{array}{l}\text { Lower } \\
\mathbf{9 5 \%}\end{array}$ & $\begin{array}{l}\text { Upper } \\
\mathbf{9 5 \%}\end{array}$ \\
\hline & Yes & 273 & 53 & 46 & 227 & 0.0006 & 0.47 & 0.31 & 0.72 \\
\hline $\mathbf{2}$ & $\begin{array}{l}\text { Children sleeping } \\
\text { under LLITN }\end{array}$ & No. & $\%$ & $\begin{array}{l}\text { malnutr } \\
\text { ition }\end{array}$ & $\begin{array}{l}\text { No } \\
\text { malnutriti } \\
\text { on }\end{array}$ & $\begin{array}{l}\boldsymbol{P} \text { - } \\
\text { value }\end{array}$ & OR & $\begin{array}{l}\text { Lower } \\
\mathbf{9 5 \%}\end{array}$ & $\begin{array}{l}\text { Upper } \\
\mathbf{9 5 \%}\end{array}$ \\
\hline & Yes & 273 & 52.9 & 50 & 223 & 0.01 & 0.57 & 0.37 & 0.86 \\
\hline & & & & & & & & \\
\hline
\end{tabular}


DOI: 10.21522/TIJPH.2013.SE.19.01.Art012

ISSN: $2520-3134$

\begin{tabular}{|c|c|c|c|c|c|c|c|c|c|}
\hline 3 & $\begin{array}{l}\text { A day of lack of } \\
\text { food/money for } \\
\text { food in the last } \\
\text { 30days prior to } \\
\text { study }\end{array}$ & No. & $\%$ & $\begin{array}{l}\text { malnutr } \\
\text { ition }\end{array}$ & $\begin{array}{l}\text { No } \\
\text { malnutriti } \\
\text { on }\end{array}$ & $\begin{array}{l}P \text { - } \\
\text { value }\end{array}$ & OR & $\begin{array}{l}\text { Lower } \\
95 \%\end{array}$ & $\begin{array}{l}\text { Upper } \\
95 \%\end{array}$ \\
\hline & Yes & 361 & $\begin{array}{l}70 \\
\% \\
\end{array}$ & 101 & 260 & 0.0001 & 2.96 & 1.72 & 5.09 \\
\hline 4 & $\begin{array}{l}\text { Agricultural } \\
\text { production }\end{array}$ & No. & $\%$ & $\begin{array}{l}\text { malnutr } \\
\text { ition }\end{array}$ & $\begin{array}{l}\text { No } \\
\text { malnutriti } \\
\text { on }\end{array}$ & $\begin{array}{l}P \text { - } \\
\text { value }\end{array}$ & OR & $\begin{array}{l}\text { Lower } \\
95 \%\end{array}$ & $\begin{array}{l}\text { Upper } \\
95 \%\end{array}$ \\
\hline & Yes & 282 & 54.7 & 49 & 233 & 0.001 & 0.49 & 0.32 & 0.75 \\
\hline 5 & $\begin{array}{l}\text { Still has Cereals } \\
\text { of last harvest }\end{array}$ & No. & $\%$ & $\begin{array}{l}\text { malnutr } \\
\text { ition }\end{array}$ & $\begin{array}{l}\text { No } \\
\text { malnutriti } \\
\text { on }\end{array}$ & $\begin{array}{l}P \text { - } \\
\text { value }\end{array}$ & OR & $\begin{array}{l}\text { Lower } \\
95 \%\end{array}$ & $\begin{array}{l}\text { Upper } \\
95 \%\end{array}$ \\
\hline & Yes & 181 & $\begin{array}{l}35 \\
\%\end{array}$ & 30 & 151 & 0.014 & 0.55 & 0.35 & 0.87 \\
\hline 6 & $\begin{array}{l}\text { CBD within Easy } \\
\text { reach }\end{array}$ & No. & $\%$ & $\begin{array}{l}\text { malnutr } \\
\text { ition }\end{array}$ & $\begin{array}{l}\text { No } \\
\text { malnutriti } \\
\text { on }\end{array}$ & $\begin{array}{l}P \text { - } \\
\text { value }\end{array}$ & OR & $\begin{array}{l}\text { Lower } \\
95 \%\end{array}$ & $\begin{array}{l}\text { Upper } \\
95 \%\end{array}$ \\
\hline & Yes & 259 & 50.2 & 49 & 210 & 0.032 & 0.62 & 0.41 & 0.94 \\
\hline 7 & $\begin{array}{l}\text { Measles } \\
\text { Vaccination }\end{array}$ & No. & $\%$ & $\begin{array}{l}\text { malnutr } \\
\text { ition }\end{array}$ & $\begin{array}{l}\text { No } \\
\text { malnutriti } \\
\text { on } \\
\end{array}$ & $\begin{array}{l}P \text { - } \\
\text { value }\end{array}$ & OR & $\begin{array}{l}\text { Lower } \\
95 \%\end{array}$ & $\begin{array}{l}\text { Upper } \\
95 \%\end{array}$ \\
\hline & $\begin{array}{l}\text { Not vaccinated } \\
\text { Yet }\end{array}$ & 201 & 39 & 60 & 141 & & & & \\
\hline & $\begin{array}{l}\text { Vaccinated with } \\
\text { Card }\end{array}$ & 284 & 55 & 49 & 235 & 0.005 & 0.54 & 0.36 & 0.82 \\
\hline & $\begin{array}{l}\text { Vaccinated } \\
\text { without card }\end{array}$ & 31 & 6 & 10 & 21 & & & & \\
\hline & Total & 516 & 100 & 119 & 397 & & & & \\
\hline
\end{tabular}

Out of the 516 care takers interviewed, 282(54.7\%) were involved in their own food production. 49 $(17.38 \%)$ of the children in these homes were malnourished with p-value of 0.001 and OR 0.49 (95\% C.I. 0.32-0.75) which was statistically significant. 181 (50\%) of those who had produced food had cereals still available by the time of administering questionnaire. 30 (10.64\%) of the children in these group who still had their food from last harvest were malnourished with p-value of 0.014 and OR 0.55 (95\% C.I. 0.350.87) which is significant (Table 16: sections 4 and 5).

Community based distributers (CBDs) were found to be within easy reach of 259 (50.2\%) of the 516 care takers interviewed. $49(18.92 \%)$ of the children with access to CBDs were malnourished with pvalue of 0.032 , OR 0.62 (95\% C.I. 0.41-0.94). P-value is significant and OR shows risk reduction to malnutrition in the presence of CBDs (table16: section 6).

\section{Multivariate analysis}

Main sources of food for the 6-59 months old children were the families own produce with estimate of 282(54.7\%). This was followed by market or shop at $123(23.9 \%)$ and work for food $67(13 \%)$. Significant number of respondents $31(6 \%)$ reported to have no food for the family hence resort to 
begging from relatives, friends and well-wishers both in town and villages; only 1(0.2\%) reported to be relying on food aid from the humanitarian workers. Source of food is a factor that affects the nutrition status of children with p-value of 0.00357 and (95\% confidence interval of $0.081-0.2)$. Those who mainly buy from the market have the least rate of malnutrition among 6-59 months old children at $16 \%$ (20) followed by those who produce their own food at $17 \%$ (47). However, those who rely on food aid have the highest rate of malnutrition at 50\% (1) followed by those who work for food at $45 \%$ (30) (table17 section 8).

The food is prepared and given to children daily, but there was wide variation in the frequency at which the food is given. 163 (57.6\%) of the children were fed once or twice in a day, $79(15.4 \%)$ were fed thrice a day and the remaining 139 (27\%) were fed four or more times a day (fig 10). Feeding children once or twice a day contributes to malnutrition with P-values $0.00035,0.4058$ and odds rations $2.20(95 \%$ C.I 1.44-3.35) and 1.24 (95\% C.I. 0.79-1.96) respectively. Meanwhile feeding young children 4 or more times a day has protective significant effect against malnutrition with p-values 0.000278 and OR 0.2 (95\% C.I. 0.08-0.5) (table17: section 1).

The study revealed high burden of infectious diseases at $94.5 \%$ and only $28(5.5 \%)$ of the children were reported not to have any illness in the past two weeks prior to the study. 225 (43.7\%) of the children were reported to have suffered from a febrile illness, 130 (25.1\%) from diarrhea, 104 (20.2\%) from cough, 23 (4.4\%) from skin infections and $6(1.1 \%)$ were reported to have suffered from eye infections (fig8).

Children 6-59 months old who were reported to have suffered from any illness were more likely to suffer from malnutrition than those who were not sick with p-values 0.043 , and 0.040 for fever, and diarrhea respectively. The odds ratios for fever and diarrhea were above 1(one) meaning that the infections contributed to the malnutrition though at varying degrees for example, odds ratio (OR) for fever was 1.56(95\% C.I 1.03- 2.36) and OR for diarrhea was 1.64 (95\% C.I 1.05-2.57). Cough has slight effect on malnutrition with OR 0.93 (95\% C.I 0.56-1.57) (table17: section 2).

The health seeking behavior for the parents or care takers however varied. 156(30.2\%) of the respondents sought health services from a community based distributer (CBD), 108 (20.9\%) went for treatment in a primary health care center (PHCC) or primary health care unit (PHCU). $88(17 \%)$ of the respondents sought health services from hospital, 23(4.4\%) from private physician within Aweil town, $53(10.3 \%)$ from drug shops, $20(3.9 \%)$ from traditional healer and $6(1.1 \%)$ from village health worker (table23).

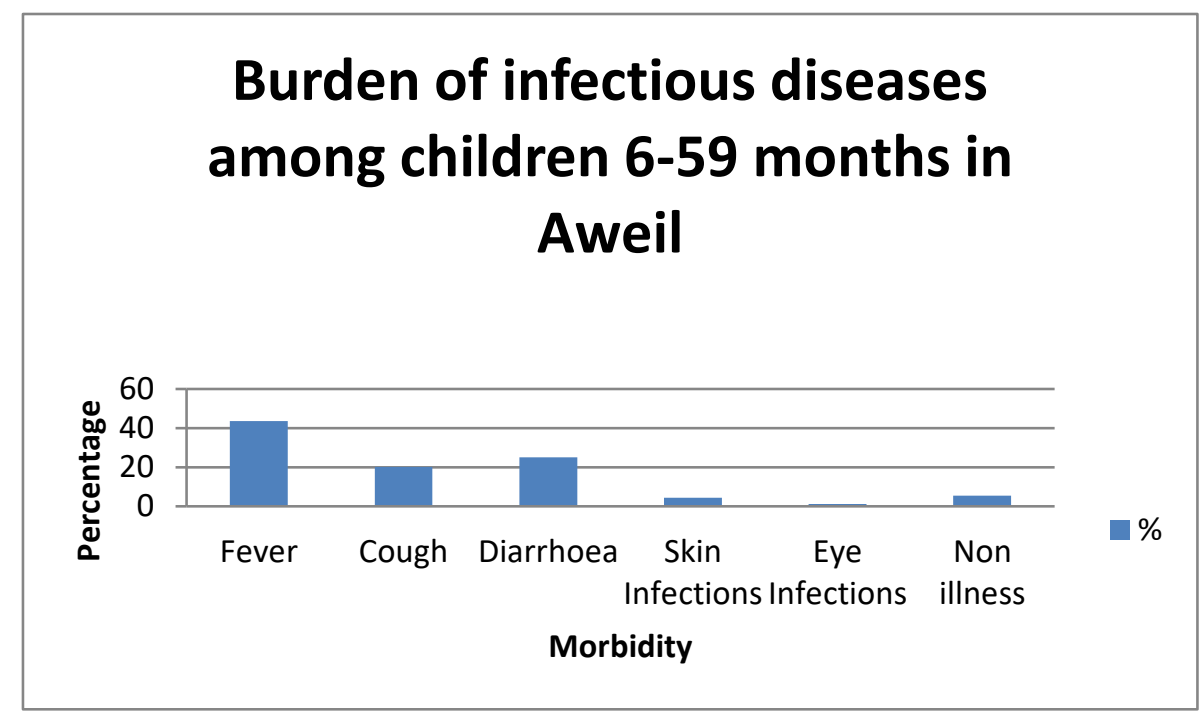

Figure 8. Burden of infectious diseases among children 6-59 months in Aweil 2 weeks prior to the study 


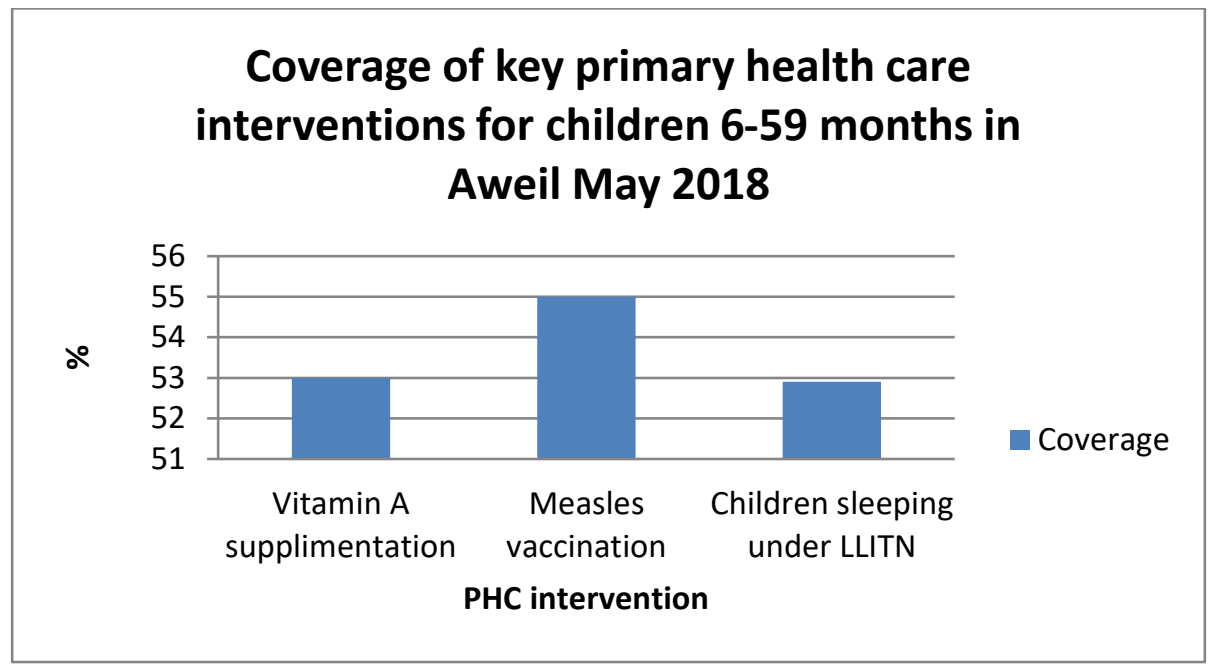

Figure 9. Coverage of key primary health care interventions for children 6-59 months in Aweil

\section{Frequencies of daily meals eaten by children 6-} 59 months in Aweil May 2018

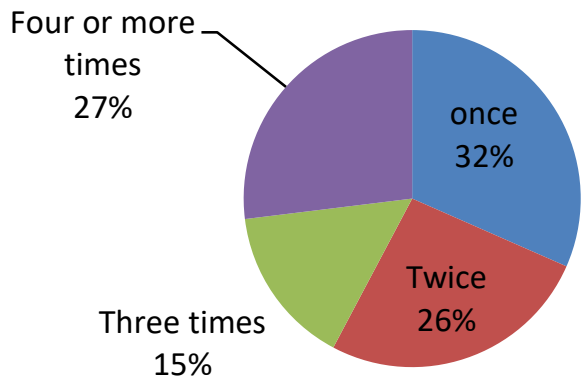

Figure 10. Frequency of meals eaten daily by children 6-59 months in Aweil center May 2018

Table 1. Table of P-values, O.R. (95\% C.I.) of different factors - multivariate analysis

\begin{tabular}{|c|c|c|c|c|c|c|c|c|c|}
\hline \multirow[b]{2}{*}{1} & \multirow{2}{*}{$\begin{array}{l}\text { VARIABLE } \\
\text { Frequencies of } \\
\text { meals eaten by } \\
\text { children }\end{array}$} & \multirow{2}{*}{$\begin{array}{l}\text { No. } \\
\text { No. }\end{array}$} & \multirow{2}{*}{$\begin{array}{l}\% \\
\%\end{array}$} & \multirow[b]{2}{*}{$\begin{array}{l}\text { Mal } \\
\text { nutritio } \\
\text { n }\end{array}$} & \multirow[b]{2}{*}{$\begin{array}{l}\text { No mal } \\
\text { nutritio } \\
\text { n }\end{array}$} & \multirow{2}{*}{$\begin{array}{l}\text { P- } \\
\text { VALUE } \\
\text { P-value }\end{array}$} & \multirow{2}{*}{\begin{tabular}{|c|} 
OR \\
OR
\end{tabular}} & \multicolumn{2}{|c|}{$95 \% \mathrm{CI}$} \\
\hline & & & & & & & & $\begin{array}{l}\text { Lower } \\
95 \%\end{array}$ & $\begin{array}{l}\text { Uppe } \\
r \\
95 \%\end{array}$ \\
\hline & Once & 163 & $\begin{array}{l}31.5 \\
0\end{array}$ & 54 & 109 & 0.00035 & 2.20 & 1.44 & 3.35 \\
\hline & Twice & 136 & $\begin{array}{l}26.1 \\
0\end{array}$ & 36 & 100 & 0.40581 & 1.24 & 0.79 & 1.96 \\
\hline & Three times & 139 & $\begin{array}{l}27.0 \\
0\end{array}$ & 24 & 115 & 0.07507 & 0.62 & 0.38 & 1.02 \\
\hline & Four or more times & 78 & $\begin{array}{l}15.0 \\
0\end{array}$ & 5 & 73 & 0.00028 & 0.20 & 0.08 & 0.5 \\
\hline & Total & 516 & $\begin{array}{l}99.6 \\
0\end{array}$ & 119 & 398 & & 0.47 & 0.040 & 0.02 \\
\hline
\end{tabular}


Texila International Journal of Public Health Special Edition Apr 2019

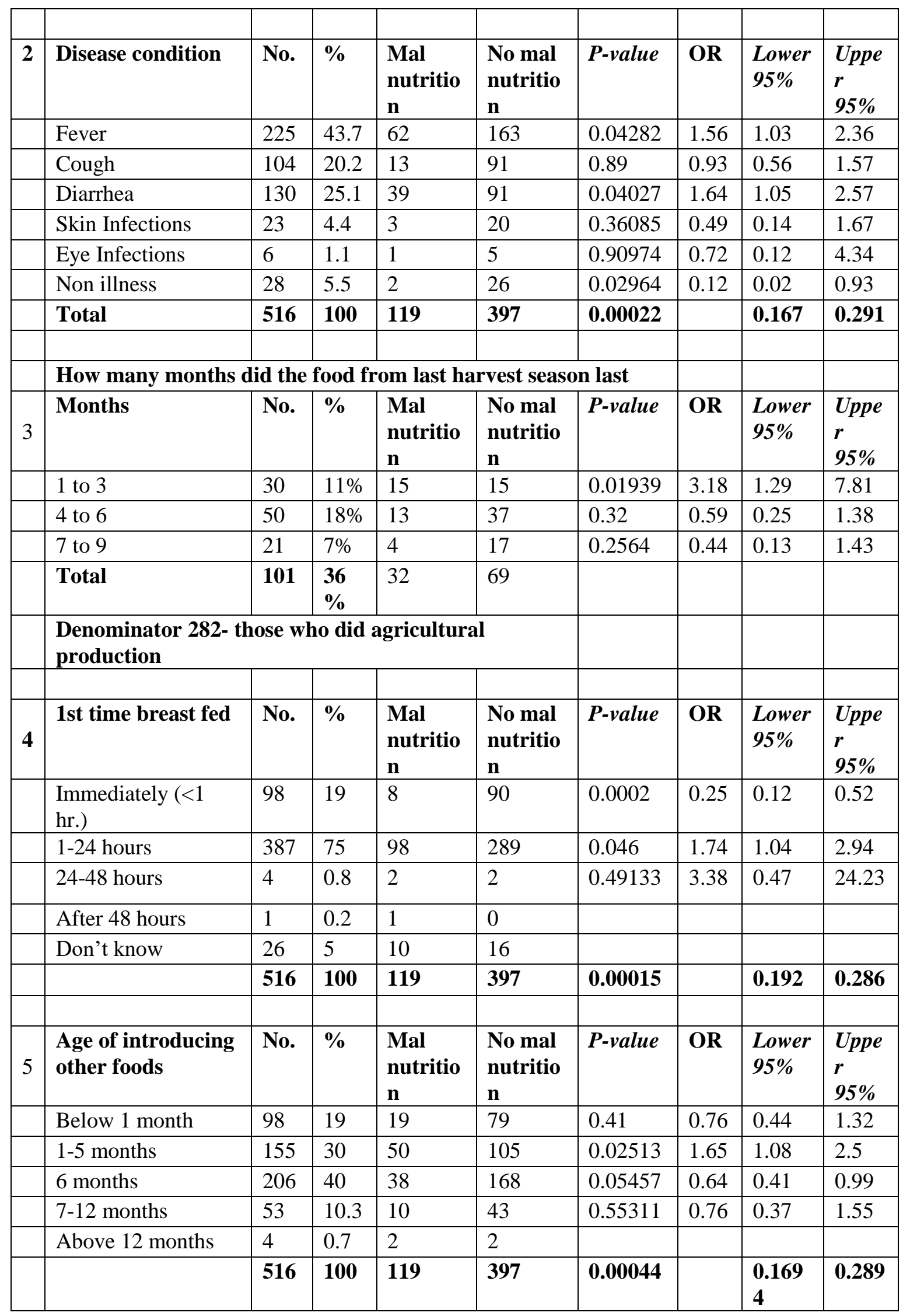


DOI: 10.21522/TIJPH.2013.SE.19.01.Art012

ISSN: 2520-3134

\begin{tabular}{|c|c|c|c|c|c|c|c|c|c|}
\hline 6 & $\begin{array}{l}\text { Mothers' } \\
\text { education level }\end{array}$ & No. & $\%$ & $\begin{array}{l}\text { Mal } \\
\text { nutritio } \\
\text { n }\end{array}$ & $\begin{array}{l}\text { No mal } \\
\text { nutritio } \\
\text { n }\end{array}$ & $P$-value & OR & $\begin{array}{l}\text { Lower } \\
95 \%\end{array}$ & $\begin{array}{l}\text { Uppe } \\
r \\
95 \%\end{array}$ \\
\hline & $\begin{array}{l}\text { Never attended } \\
\text { school }\end{array}$ & 397 & 76.9 & 102 & 295 & 0.01362 & 2.07 & 1.18 & 3.63 \\
\hline & Primary level & 98 & 19 & 10 & 88 & 0.00126 & 0.39 & 0.21 & 0.72 \\
\hline & Secondary level & 13 & 2.5 & 4 & 9 & 0.72440 & 1.52 & 0.46 & 5.02 \\
\hline & Institution & 8 & 1.6 & 3 & 5 & 0.57950 & 2.03 & 0.48 & 8.61 \\
\hline & & 516 & 100 & 119 & 397 & 0.00035 & & $\begin{array}{l}0.203 \\
1 \\
\end{array}$ & 0.288 \\
\hline 7 & $\begin{array}{l}\text { Age of the Mother } \\
\text { or care taker }\end{array}$ & No. & $\%$ & $\begin{array}{l}\text { Mal } \\
\text { nutritio } \\
\text { n }\end{array}$ & $\begin{array}{l}\text { No mal } \\
\text { nutritio } \\
\text { n }\end{array}$ & $P$-value & OR & $\begin{array}{l}\text { Lower } \\
95 \%\end{array}$ & $\begin{array}{l}\text { Uppe } \\
r \\
95 \%\end{array}$ \\
\hline & Less than 20 & 166 & 32 & 49 & 117 & 0.0347 & 1.62 & 1.06 & 2.47 \\
\hline & $20-29$ & 133 & 25.8 & 70 & 103 & 0.96712 & 0.96 & 0.6 & 1.54 \\
\hline & $30-39$ & 144 & 27.9 & 29 & 115 & 0.38744 & 0.79 & 0.49 & 1.27 \\
\hline & $40-49$ & 65 & 12.6 & 10 & 55 & 0.1573 & 0.57 & 0.28 & 1.16 \\
\hline & 50 and above & 8 & 2 & 1 & 7 & & & & \\
\hline & & 516 & 100 & 119 & 397 & 0.00107 & & 0.158 & 0.312 \\
\hline
\end{tabular}

\section{Food security factors}

Table 18. Individual Dietary Diversity Score (IDDS) of children who ate at least 4 types of food 24 hours prior to the study

\begin{tabular}{|l|l|l|l|}
\hline Age Category & No. & $\mathbf{f , 4}$ or more food eaten & IDDS (\%) \\
\hline$(6-11)$ & 56 & 7 & 12.5 \\
\hline$(12-23)$ & 131 & 12 & 9.2 \\
\hline$(24-35)$ & 110 & 30 & 27.3 \\
\hline$(36-47)$ & 109 & 20 & 18.3 \\
\hline$(48-60)$ & 110 & 15 & 13.6 \\
\hline Total & $\mathbf{5 1 6}$ & $\mathbf{8 4}$ & $\mathbf{1 6 . 3}$ \\
\hline
\end{tabular}

84(16.28\%) mothers and care takers reported to have fed the child 4 or more types of food in $24 \mathrm{hrs}$ prior to the study. This was equivalent to $16.3 \%$ individual dietary diversity score with p-value of 0.001459 (C.I, 0.104461-0.212) which was significant (Table 8).

$125(24 \%)$ of the households had consumed various food types 4-7 times 7 days prior to the day of the questionnaire. The commonest foods consumed by the family were milk and milk products by 200 families, fish by 148 families, and fruits by 141 followed by cereals consumed by 136 families. Meanwhile the least food consumed were tubers and roots consumed by 97 families. (Table9). 
Table 19. Number of days in past 7 days household had consumed the group of foods-household dietary diversity score (HDDS)

\begin{tabular}{|c|c|c|c|c|}
\hline Food group & Never & 1-3times & 4-7 times & HDDS \\
\hline Cereals & 5 & 375 & 136 & $26 \%$ \\
\hline Legumes/nuts & 53 & 350 & 113 & $22 \%$ \\
\hline Roots \& tubers & 39 & 380 & 97 & $19 \%$ \\
\hline Meat/poultry & 50 & 309 & 107 & $21 \%$ \\
\hline Fish \& sea food & 103 & 272 & 141 & $27 \%$ \\
\hline Milk \& milk products & 16 & 300 & 200 & $39 \%$ \\
\hline Vegetables & 84 & 320 & 112 & $22 \%$ \\
\hline Fruits & 108 & 260 & 148 & $29 \%$ \\
\hline Eggs & 172 & 240 & 104 & $20 \%$ \\
\hline Oil / fats & 174 & 226 & 116 & $22 \%$ \\
\hline Sugar \& honey & 106 & 310 & 100 & $19 \%$ \\
\hline Average & 83 & 304 & 125 & $24 \%$ \\
\hline
\end{tabular}

Table 20. Age of siblings of children with malnutrition- Mothers with other children (n) $=387$

\begin{tabular}{|l|l|l|l|l|l|}
\hline Age of other children & No. & $\boldsymbol{\%}$ & Malnutrition & No malnutrition & Prevalence \\
\hline$(0-5)$ & 50 & $13 \%$ & 16 & 34 & $32 \%$ \\
\hline$(6-11)$ & 79 & $20 \%$ & 30 & 49 & $38 \%$ \\
\hline$(12-23)$ & 40 & $10 \%$ & 20 & 20 & $50 \%$ \\
\hline$(24-35)$ & 89 & $23 \%$ & 12 & 77 & $13 \%$ \\
\hline$(36-47)$ & 94 & $24 \%$ & 9 & 85 & $10 \%$ \\
\hline$(48-60)$ & 35 & $9 \%$ & 5 & 30 & $14 \%$ \\
\hline Total & $\mathbf{3 8 7}$ & $\mathbf{1 0 0 \%}$ & $\mathbf{9 2}$ & $\mathbf{2 9 5}$ & \\
\hline
\end{tabular}

Table21. Main shock faced by the households in aweil center

\begin{tabular}{|l|l|l|l|l|}
\hline Shocks & No. & $\mathbf{\%}$ & Malnutrition & No malnutrition \\
\hline No shocks & 5 & $1 \%$ & 0 & 5 \\
\hline Insecurity & 26 & $5 \%$ & 5 & 21 \\
\hline Expensive food & 187 & $36 \%$ & 83 & 104 \\
\hline $\begin{array}{l}\text { Limited access to basic } \\
\text { services }\end{array}$ & 13 & $3 \%$ & 3 & 10 \\
\hline Diseases & 252 & $49 \%$ & 21 & 231 \\
\hline Floods & 10 & $2 \%$ & 2 & 8 \\
\hline Livestock diseases & 3 & $1 \%$ & 1 & 2 \\
\hline Delay of rains & 5 & $1 \%$ & 1 & 4 \\
\hline Pest/crop disease & 10 & $2 \%$ & 1 & 9 \\
\hline Lack of water & 5 & $1 \%$ & 2 & 3 \\
\hline Total & $\mathbf{5 1 6}$ & $\mathbf{1 0 0 \%}$ & $\mathbf{1 1 9}$ & $\mathbf{3 9 7}$ \\
\hline
\end{tabular}

Aweil has overwhelming number of problems with varying gravity that affect the social economic wellbeing of the families and impact on the nutrition status of the children especially those 6-59 months with p-value of 0.0001 (95\% C.I 0.1443-0.3025) which was significant. 99\% (511) mothers reported at 
DOI: 10.21522/TIJPH.2013.SE.19.01.Art012

ISSN: $2520-3134$

least one of the following shocks: diseases 252(49\%), high cost of food 187(36\%), insecurity 26(5\%), limited access to basic services $13(3 \%)$ and floods $10(2 \%)$ among others (table10).

One of the findings is the relation between malnutrition and the age of the youngest sibling with pvalue 0.001 at $(95 \%$ C.I $0.1442-0.3167)$. $50(13 \%)$ of the respondents reported that there was a younger child (1-5 months) and 79 (15\%) reported younger child of 6-11 months and the rest reported siblings older to the one who was being enrolled into the study. Generally, the younger the youngest sibling, the greater the risk of malnutrition for the other child with the highest prevalence of malnutrition at $50 \%$ among children 12-23 months age group and followed by $38 \%$ among 6-11\% age group. The list prevalence was $10 \%$ among the age group of $36-47 \%$ (table 11 ).

Table 22. Main sources of household income in Aweil

\begin{tabular}{|l|l|l|l|l|l|}
\hline $\begin{array}{l}\text { Main sources of household } \\
\text { income }\end{array}$ & No. & $\boldsymbol{\%}$ & $\begin{array}{l}\text { Malnutri } \\
\text { tion }\end{array}$ & $\begin{array}{l}\text { No } \\
\text { malnutritio } \\
\text { n }\end{array}$ & $\begin{array}{l}\text { \% } \\
\text { Malnutritio } \\
\text { n }\end{array}$ \\
\hline Sale of crops & 253 & 49 & 77 & 170 & $30 \%$ \\
\hline Sale of livestock & 10 & 2 & 3 & 7 & $1 \%$ \\
\hline Sale of animal products & 5 & 1 & 1 & 4 & $20 \%$ \\
\hline $\begin{array}{l}\text { Sale of natural resources like local } \\
\text { building materials, honey, firewood }\end{array}$ & 103 & 20 & 10 & 93 & $10 \%$ \\
\hline Casual labor & 31 & 6 & 3 & 28 & $10 \%$ \\
\hline Salaried and skilled labor & 41 & 8 & 2 & 38 & $6 \%$ \\
\hline Small business & 36 & 7 & 6 & 30 & $17 \%$ \\
\hline Brewing & 26 & 5 & 15 & 11 & $42 \%$ \\
\hline Sale of fish & 5 & 1 & 1 & 4 & $20 \%$ \\
\hline Other & 4 & 1 & 1 & 4 & $20 \%$ \\
\hline Total & $\mathbf{5 1 4}$ & $\mathbf{1 0}$ & $\mathbf{1 1 9}$ & $\mathbf{3 8 9}$ & $\mathbf{2 3 \%}$ \\
\hline
\end{tabular}

$15(3 \%)$ of the care takers sale livestock or their products like milk; majority- 253(49\%) sale of crops as their main source of income. $103(20 \%)$ of them reported sale of natural resources like grass, poles, firewood and honey as their main source of household income. 41(8\%) of the respondents had skilled labor with salary jobs. $31(6 \%)$ worked as casual laborers, 36(7\%) were small scale business women/men and 26(5\%) reported local brewing as their source of household income (table12).

Table 23. Health seeking behavior among the caretakers in Aweil Center

\begin{tabular}{|l|l|l|}
\hline Health seeking behavior & No. & \% \\
\hline Hospital & 88 & 17 \\
\hline PHCC/U & 108 & 20.9 \\
\hline CBD & 156 & 30.2 \\
\hline Private Physician & 23 & 4.4 \\
\hline Village health worker & 6 & 1.1 \\
\hline Traditional healer & 20 & 3.9 \\
\hline Drug shop & 53 & 10.3 \\
\hline Other & 63 & 12.2 \\
\hline Total & $\mathbf{5 1 6}$ & $\mathbf{1 0 0}$ \\
\hline
\end{tabular}




\section{Discussion}

The results achieved the $1^{\text {st }}$ objective of assessing the prevalence of malnutrition among children 6-59 months in Aweil Center County. It showed that prevalence of global acute malnutrition - GAM rate at $(<-$ $2 \mathrm{z}$-score and/or edema) was [119] 23.2\% (95\% CI, 19.0- 27.9) which was above the WHO threshold of $15 \%$. Similarly prevalence of moderately acute malnutrition (MAM) (<-2 z-score and $>=-3$ z-score, no edema) was $16.2 \%$ ( $95 \%$ CI, 14.1-18.0) (table2). This was also above the threshold of $8 \%$ for MAM recommended by the global nutrition cluster (GNC). Prevalence of severe acute malnutrition (SAM) (\% < -3SD) was 7\% (95\% CI, 4.9-9.9) in Aweil which was also higher than the WHO threshold of 2\%.

This finding was consistent with the results of 2017 publication of another study done by WHO staff that showed that former northern Bahr el Ghazal state where Aweil Center is the capital had GAM rate above the emergence threshold and was staggering at catastrophic level of $33.3 \%$ by 2015 (Adrianopoli $M$ and Mpairwe A 2017). Neighboring Sudan state of North Darfur where Global Acute Malnutrition (GAM) prevalence is at 27.9 per cent has been in conflict for over decades like South Sudan leading to chronic underdevelopment which in turn resulted in to acute humanitarian needs (WHO 2017).

In relation to the second objective, 256(49\%) of the respondents reported to have another younger sibling to the one enrolled in the study (table11). This is an indication of too close child spacing which gives little attention to the older child once the new baby is born hence he/she is likely to be weaned off breast milk too early with limited nutrition options; hence risk of becoming malnourished. This practice is however deeply rooted in the culture of South Sudanese leading to the high fertility rate of 7.1 children per woman (Hilde H. H. 2017).

The study revealed high burden of infectious diseases at $94.5 \%$ with p-value 0.00022 (95\% C.I, $0.1667-0.291$ ) and only $28(5.5 \%)$ of the children were reported not to have any illness in the past two weeks prior to the study as indicated in objective three of the study. 225 (43.7\%) of the children were reported to have suffered from a febrile illness. These findings are consistent with that of WHO published in July 2018 which showed malaria (commonest cause of febrile illness) as the leading cause of morbidity accounting for $63 \%$ of the consultations.

The relationship between diarrhea and malnutrition is bidirectional: diarrhea leads to malnutrition and if chronic, can lead to stunting by $25-30 \%$ while malnutrition aggravates the diarrhea especially in children (Visser J, Blaauw R, and Labadarios D 2010).

Prevalence of stunting based on height/length-for-age z-scores was $8.7 \%$ (95\% CI, 6.5- 11.6). Comparing the rate of stunting with the history of chronic malnutrition, the prevalence of stunting is much lower than expected most likely due to the associated genetic factors that the population of this pastoral community are genetically tall people.

$163(57.6 \%)$ of the children were fed once or twice in a day, $79(15.4 \%)$ were fed thrice a day and the remaining $139(27 \%)$ were fed four or more times a day with individual dietary diversity score of $16.3 \%$ with p-value of 0.001459 (C.I, 0.104461-0.212) which was significant (fig 10 and table 8). To provide food once or twice a day for young children with high metabolic rate can lead to malnutrition. This partly explains the chronic malnutrition in Aweil that has persisted in years. The community may not be aware that children need more frequent feeding than adults to prevent malnutrition.

Main sources of food for the 6-59 months old children were, the families own produce with estimate of 282(54.7\%). This was followed by market or shop at $123(23.9 \%)$ and work for food 67 (13\%). Significant number of respondents $31(6 \%)$ reported to have no food for the family hence resort to begging from relatives, friends and well-wishers both in town and villages; only $1(0.2 \%)$ reported to be relying on food aid from the humanitarian workers(table12). This partly reflects the inaccessibility of the remote areas by the aid workers for food aid. In South East Asia it is shown that the production of targeted nutrition-rich crops, homestead gardens, and diversification of the agricultural production system towards fruits and vegetables and aquaculture potentially improves nutrient intake and nutritional outcomes (Pandey L.V, Mahendra D. S, and Jayachandran U 2016).

Vitamin A supplementation for children 6-59 months was 273(53\%) which is low coverage though 
DOI: 10.21522/TIJPH.2013.SE.19.01.Art012

ISSN: 2520-3134

answers objective four of the study. Vitamin A deficiency (serum retinol $0.70 \mu \mathrm{mol} / \mathrm{l}$ or lower) is $20 \%$ in infants and children 6-59 months of age which need to be corrected through Vitamin A supplementation (WHO 2018) (fig9).

Measles vaccination with evidence from a vaccination card was only $284(55 \%)$. This is poor measles coverage that cannot provide hard immunity to the children in the community. At least $95 \%$ coverage is needed to attain hard immunity.

$273(53 \%)$ of the children were reported to be sleeping under long lasting insecticide treated mosquito nets. With high prevalence of infectious diseases over $40 \%$ of which were fever, preventive measures like LLITN mass distribution and proper use need to be promoted (figure 9).

\section{Limitations of the study}

I. The study didn't consider the residence status of the households or children whether some of them were IDPs from the neighboring states where there is conflict that could be more vulnerable to malnutrition than the host community.

II. This study was cross-sectional done in May; hence it does not reflect the seasonal variation of malnutrition during the pre-harvest, harvest and hanger gaps.

\section{Conclusion}

This study confirms the prevalence of malnutrition among children that remains chronically high above the WHO's threshold of $15 \%$ in Aweil center and situation is worse by poor family planning, high burden of infectious diseases, dependency syndrome on inadequate food aid in the villages where the accessibility for basic services is hampered by flooding during the rainy season which calls for infrastructure development at the Payam level to increase accessibility to basic services.

\section{References}

[1]. Akombi BJ, Agho KE, Merom D, Renzaho AM, Hall JJ (2017) Child malnutrition in Sub-Saharan Africa: A meta-analysis of demographic and health surveys (2006-2016). PLoS ONE 12(5): e0177338

[2]. Adrianopoli M. and Mpairwe A.2017. WHO emergency nutrition response in South Sudan https://www.ennonline.net/fex/53/whoinsouthsudan

[3]. FAO 2010. Guidelines for measuring household and individual dietary diversity. fao_guidelines_for_measuring_dietary_diversity_2010_october

[4]. Hilde H. H. 2017. Reproductive health causes tension in South Sudan

[5]. Keane E, King A, Awira A and Koyoki L 2013. Integrating severe acute malnutrition into the management of childhood diseases at community level in South Sudan. https://www.malariaconsortium.org/media-downloads/248/

[6]. Ketut Aryastami K N, Shankar A, Kusumawardani N, Besral B, Jahari B, A and Achadi E 2017. Low birth weight was the most dominant predictor associated with stunting among children aged 12-23 months in Indonesia. BMC Nutrition (2017) 3:16 DOI 10.1186/s40795-017-0130-x

[7]. Pandey L.V, Mahendra D. S, and Jayachandran U 2016. Impact of agricultural interventions on the nutritional status in South Asia: A review. PMC4952527

[8]. Phillip Harvey and Beth Rogers, 2007. Nutrition status and its determinants in Southern Sudan. A2Z_SouthSudan_Doc_MEH_Edits_09.23.08.doc

[9]. Phiri, Thokozani 2014. "Review of Maternal Effects on Early Childhood Stunting." Grand Challenges Canada

Economic Returns to Mitigating Early Life Risks Project Working Paper Series, 2014-18. https://repository.upenn.edu/gcc_economic_returns/18

[10]. Southern Sudan Centre for Census, Statistics and Evaluation (SSCCSE) 2010. Poverty in Southern Sudan: Estimates from NBHS (2010)

[11]. United Nations 2015. The Millennium Development Goals Report 2015

[12]. UNICEF 2015, Progress for Children Beyond averages: learning from the MDGs. NUMBER 11, 2015 
[13]. Visser J, Blaauw R, and Labadarios D 2010. 2010 Congress Supplement. Clinical Nutrition Challenges: Evidence vs Practice. S Afr J Clin Nutr S1 2010;23(1) Supplement

[14]. WHO, 1999. Management of severe malnutrition: a manual for physicians and other senior health workers. Geneva

[15]. WHO, 2003. Global strategy for infant and young child feeding. Geneva.

[16]. WHO, 2017. Nutrition in the WHO African Region. Brazzaville: World Health Organization; 2017

[17]. World health organization2015. Vaccination coverage cluster surveys: Reference manual. https://www.who.int/immunization/monitoring_surveillance/Vaccination_coverage_cluster_survey_with_annexes.p df

[18]. WHO 2017. Sudan Humanitarian Response Plan 2017. Health sector situation http://www.who.int/emergencies/response-plans/2017/sudan/en/

[19]. WHO 2018. Vitamin A supplementation in infants and children 6-59 months of age. E-Library of Evidence for Nutrition Actions (eLENA). 